\title{
INFLUENCE OF TILLAGE TECHNIQUES AND ORGANIC MATTER ON CARBON AND NITROGEN TRANSFORMATION IN THE RICE RHIZOSPHERE IN AN ALLUVIAL SOIL OF WEST BENGAL
}

\author{
PATRA, P.K. ${ }^{1}-$ SAHA, N..$^{1 *}$ MUKHERJEE, R. $^{2}-$ CHAKRABORTY, A. ${ }^{2}-$ SARKAR, ${ }^{3}{ }^{3}-$ \\ MUKHERJEE, D. ${ }^{1}$ \\ ${ }^{I}$ Department of Agricultural Chemistry and Soil Science \\ ${ }^{2}$ Department of Agricultural Biochemistry \\ ${ }^{3}$ Department of Agricultural Meteorology and Physics Bidhan Chandra Krishi Viswavidyalaya, \\ P.O. - Krishi Viswavidyalaya, Mohanpur 741252, Nadia, West Bengal, India \\ (phone+91-9433777855; fax +91-033-25828460) \\ *Corresponding author \\ e-mail:nihar_bckv@rediffmail.com \\ (Received $6^{\text {th }}$ January 2009 ; accepted $28^{\text {th }}$ January 2010)
}

\begin{abstract}
The investigation highlights results of a field experiment conducted in an Inceptisol in the Lower Gangetic Plain of India to evaluate the sole and interactive effect of different degree of puddling through various tillage implements and farm yard manure (FYM) on carbon and nitrogen transformation in the rice rhizosphere over two seasons. Three methods of puddling viz., (1) Light puddling with country plough, (2) Moderate puddling with tractor drawn cultivator and (3) Intensive puddling with power tiller, were employed in specified triplicate plots with and without application of FYM and their effect on organic carbon, microbial biomass carbon, $\mathrm{NH}_{4}{ }^{+}-\mathrm{N}, \mathrm{NO}_{3}{ }^{-} \mathrm{N}$ and total nitrogen in the rice rhizosphere soil were assessed. The results of this study revealed that while light puddling induced the highest build up of soil organic carbon, microbial biomass carbon and total nitrogen. Moderate puddling effectuated the highest level of $\mathrm{NH}_{4}{ }^{+}-\mathrm{N}$ and $\mathrm{NO}_{3}{ }^{-} \mathrm{N}$ suggesting the highest rate of mineralization of organic- $\mathrm{N}$ in rice rhizosphere. Irrespective of puddling intensity, FYM escalated its positive effects. The highest level of $\mathrm{NO}_{3}{ }^{-}-\mathrm{N}$ was induced through the rhizosphere during flowering stage. All the chemical and biochemical attributes of the soil, except $\mathrm{NO}_{3}{ }^{-} \mathrm{N}$, were stimulated to the greatest extent during tillering stage. From this research results moderate puddling could be suggested for the best nitrogen availability during the critical growth stages of rice.
\end{abstract}

Keywords: Tillage, Organic matter, $N$ transformation, rice, rhizosphere

\section{Introduction}

Rice has always played a very important role in India's food security and civilization and is the staple food for more than 2.5 billion people in Asia and many more millions in Africa and Latin America. To feed the increasing global population, annual production of rice must increase from the present level to at least $760 \mathrm{Mt}$ by the year 2020 (Kundu and Ladha, 1995). The future of the food security system, not only in India but the whole of Asia, banks upon the ability to achieve a trend of growth towards productivity and profitability of rice farming systems on an ecologically sustainable basis (Swaminathan, 1993). However, the recent trend since early 1980s has been showing downward compound growth rate in area, production and productivity of rice (Taimani and Verma, 1998). Yield stagnation and even decline in rice yield in Asia are commonly associated with gradual decline in the supply of soil nutrients especially 
nitrogen (Flinn and De Datta, 1984) and soil organic carbon (Cassman et al., 1995; Duxbury et al., 2000; Yadav et al., 1998; 2000). Though the role of fertilizer $\mathrm{N}$ in enhancing $\mathrm{N}$ mineralization rate in soil (Bouldin, 1986; Broadbent, 1979) and soil $\mathrm{N}$ uptake by wetland rice (De Datta and Broadbent, 1990) is well understood, data obtained from several field experiments under diverse soil and climatic conditions suggest that a major part ranging from 56-93\% of the total $\mathrm{N}$-requirement of wetland rice crop even when supplied with adequate fertilizer $\mathrm{N}$ particularly during heading to maturity stage (Wada et al., 1986) is met from soil organic N source (Broadbent, 1979). So, different management approaches must be evolved to explore this otherwise biggest $\mathrm{N}$ source for economical use of $\mathrm{N}$-fertilizer.

The quality of cultivated soil is affected by various agricultural practices and among them tillage holds an important place. It is important that the soil management system provide agricultural sustainability and minimal detrimental effect on the environment. Puddling, the mechanical manipulation of soil, is important for making soil condition favorable for transplanting of rice seedlings. But puddling exposes soil aggregates and results in destruction of stable soil aggregates leading to microbial decomposition of the exposed clay-organic matter complexes and, thus, causes loss of soil organic matter. The fate and behavior of soil organic matter are regulated by the degree of intensity of soil tillage. When crop residues remain on the surface, the oxidation rate of organic matter is reduced and soil organic matter accumulates on the soil surface (Beare et al., 1994). Intensive tillage like puddling, loosen and invert soil and makes soil more friable and allows greater oxygen diffusion resulting in higher activity of aerobic micro flora which, in turn, effectuate a rapid loss of $\mathrm{CO}_{2}$ form soil (Reicosky and Lindstrom, 1995). Moreover, puddling exposes higher surface area of soil and so greater interaction among inanimate constituents including minerals as well as organics in soil and biotic constituents is achieved. This in turn, effectuates enhancement in aerobic microbial decomposition of incorporated residues resulting in a net decrease in soil organic carbon (Reicosky and Lindstrom, 1995). Management system based on reduction of soil disturbance and tillage depth leads to an accumulation of organic matter (Campbell et al., 1998; Costantini et al., 1996) and enrichment of soil $\mathrm{N}$ and soil P (Diaz-Zorita and Grove, 2002; Zibilske et al., 2002).

Soil organic carbon is an important index of soil quality and so plays a crucial role in sustaining crop productivity and environmental quality (Campbell et al., 1996; Doran, 1980; Lal et al., 1997) by rejuvenating soil physical, chemical and biological properties viz., soil water retention and availability, nutrient cycling, gas flux, plant root growth and soil conservation (Gregorich, 1994). Soil microorganisms play integral role in nutrient cycling, soil stabilization and organic matter decomposition. Greater soil disturbance decrease average microbial biomass (Follett and Schimel, 1989) while minimum tillage practice provides means to reduce loss of carbon (Morris et al., 2004). So, appropriate land use and soil management practices make a dent for the improvement in soil organic carbon and so soil quality besides mitigating partially the rise of atmospheric $\mathrm{CO}_{2}$ (Lal and Bruce, 1999; Paustian et al., 1997). Among the carbon pools in soil, soil microbial biomass carbon is the only living entity. It quickly interacts and manifests status of soil health well in advance as microbes are closely associated with soil matrix. Thus, the effect of puddling intensity on rice rhizosphere can be assessed through this tool.

Incorporated organic matter in soil holds a huge potential to mitigate the adverse effects of tillage to a great extent by improving soil microbial biomass pool (Doran, 
1980), carbon, nitrogen and other nutrient transformation (Campbell et al., 1998) through improvement of enzymatic activities (Flinn and De Datta, 1984). Proper puddling of rice soils in combination with organic matter management may lead to improvement of rice crop growth, maintain proper ecology of the rhizosphere and may ultimately lead to higher production- both quantitatively and qualitatively, on a sustainable basis.

The present research project was undertaken to study the influence of different puddling practices varying in the intensity and depth of ploughing practices in combination with farm yard manure on soil organic carbon and nitrogen transformation in an alluvial (Inceptisol) soil of Eastern India.

\section{Materials and methods}

\section{Site and soil information}

The investigation comprises two field experiments in succession during kharif (Rainy; July-October), 2003 and rabi (pre-summer; January-April) season of 2004 at the Central Research Farm of Bidhan Chandra Krishi Viswavidyalaya at Gayespur located at $22^{\circ} 58^{\prime} \mathrm{N}$ and $88^{\circ} 31^{\prime} \mathrm{E}$ at an elevation of $9.75 \mathrm{~m}$ above mean sea level (MSL). The Research Farm is situated in the sub-humid zone of eastern India. Soil of the experimental site is classified as fine loamy Aeric Haplaquept. Some of the basic chemical, physico-chemical and bio-chemical properties of the surface $(0-15 \mathrm{~cm})$ soil are presented in Table 1.

Table 1. Some important characteristics of the experimental soil

\begin{tabular}{|l|c|}
\hline Parameters & Values \\
\hline Textural class & Sandy loam \\
\hline Sand $(\%)$ & 51.7 \\
\hline Silt $(\%)$ & 17.1 \\
\hline Clay $(\%)$ & 17.1 \\
\hline $\mathrm{pH}(1: 2.5$ Soil: Water ratio) & 7.45 \\
\hline Electrical conductivity $\left(\mathrm{dS} \mathrm{m} \mathrm{m}^{-1}\right)$ & 1.916 \\
\hline CEC $\left[\right.$ C.mole $\left.\left(\mathrm{p}^{+}\right) \cdot \mathrm{kg}^{-1}\right]$ & 12.8 \\
\hline Organic carbon $\left(\mathrm{g} \cdot \mathrm{kg}^{-1}\right)$ & 4.80 \\
\hline Total N $\left(\mathrm{g} \cdot \mathrm{kg}{ }^{-1}\right)$ & 0.47 \\
\hline Ammonium $-\mathrm{N}\left(\mathrm{kg}^{-1} \mathrm{ha}^{-1}\right)$ & 130.16 \\
\hline Nitrate $-\mathrm{N}\left(\mathrm{kg} \cdot \mathrm{ha}^{-1}\right)$ & 127.32 \\
\hline Available P $\left(\mathrm{kg} \cdot \mathrm{ha}^{-1}\right)$ & 9.70 \\
\hline Available K $\left(\mathrm{kg} \cdot \mathrm{ha}^{-1}\right)$ & 128.27 \\
\hline Microbial biomass carbon $\left(\mu \mathrm{g} . \mathrm{g}^{-1}\right)$ & 28.65 \\
\hline
\end{tabular}

\section{Field investigation}

Three puddling methods typical to the region were implemented: conventional light, moderate and intense puddling. Conventional light puddling, to a depth of 0-50 mm, was accomplished by an indigenous plough made of wood with an iron soil cutting edge which causes no inversion (Kamble and Srivastava, 2003), while moderate puddling, to a depth of 0-100 mm, was accomplished by using a spring tine cultivator drawn by a tractor fitted with cage wheels and intense puddling to a depth of $0-150 \mathrm{~mm}$, was accomplished by a rotary power tiller. Surface leveling was done by a horizontal wooden beam (indigenous leveler). Factorial combination of these tillage methods and 2 
levels of organic manure viz., (1) No Organic Manure $\left(\mathrm{F}_{1}\right)$ and (2) Farm Yard Manure 7.5 t.ha $^{-1}\left(\mathrm{~F}_{2}\right)$, were applied in $(10 \mathrm{~m} \times 8 \mathrm{~m})$ triplicate plots in a Randomized Complete Block Design. Three weeks old healthy seedlings of rice variety Satabdi at 3-4 seedlings.hill ${ }^{-1}$ were transplanted at $25 \mathrm{~cm}$ x $10 \mathrm{~cm}$ spacing. Fertilizer nitrogen $80 \mathrm{~kg} . \mathrm{ha}^{-1}$ as urea, phosphorus $60 \mathrm{~kg} \cdot \mathrm{ha}^{-1}$ as single super phosphate and potassium $40 \mathrm{~kg} \cdot \mathrm{ha}^{-1}$ as muriate of potash were applied to each plot. While phosphorus and potassium were applied at a time as basal dressing during final land preparation, nitrogen was applied in three equal splits. Irrigation, intercultural operations including pest and disease management were done as and when necessary. The crop was grown to maturity.

\section{Collection and analyses of soil samples}

Initial bulk surface $(0-150 \mathrm{~mm})$ soil samples were collected from field before the start of the experiment. Soil samples from each plot were also collected during critical growth periods like: tillering, flowering and maturity. The soil samples were analyzed for $\mathrm{pH}$ in 1:2.5 soil: water suspension (Jackson, 1973), oxidisable soil organic carbon by the method of Walkley and Black (1934), total nitrogen by wet digestion and Kjeldahl distillation method (Jackson, 1973), ammonium and nitrate nitrogen after extraction with $\mathrm{KCl}$ solution and Kjeldahl distillation method using Devarda's alloy for nitrate (Jackson, 1973), available P following the method of Olsen et al. (1954), available K by $1 \mathrm{~N} \mathrm{NH}_{4} \mathrm{OAC}$ using a flame photometer (Jackson, 1973) and microbial biomass carbon by method described by Joergenson (1995). Core sampler was used for soil bulk density determination. Soil texture was determined by Bouyoucos hydrometer (Bouyoucos, 1962). Soil samples collected during different stages of rice growth were also analyzed for oxidisable soil organic carbon, total nitrogen, ammonium and nitrate nitrogen and microbial biomass carbon following standard methods described above.

\section{Statistical analysis}

Statistical significance of treatment effects on different properties of soil was inferred from least significant difference (LSD, $\mathrm{P}=0.05$ ) test using analysis of variance from a Randomized Complete Block Design.

\section{Results and discussion}

\section{Organic Carbon}

Perusal of results (Table 2) reveal that conventional light puddling with country plough caused a significant increase in the organic carbon level, as compared to the other puddling methods, in the rice rhizosphere during each of the growth stages. The impact was further accelerated by the applied FYM to the soil. The increase in the organic carbon level of rhizosphere soil was due to less exposure of soil particles resulting in lower availability of autochthonous micro-flora on soil organic matter. The result substantiated the report of Doran (1980). 
Table 2. Effect of puddling practices and farm yard manure (FYM) on soil rhizosphere organic carbon status $\left(\mathrm{g}_{\mathrm{kg}} \mathrm{k}^{-1}\right)$ at different crop growth stages during two rice growing seasons

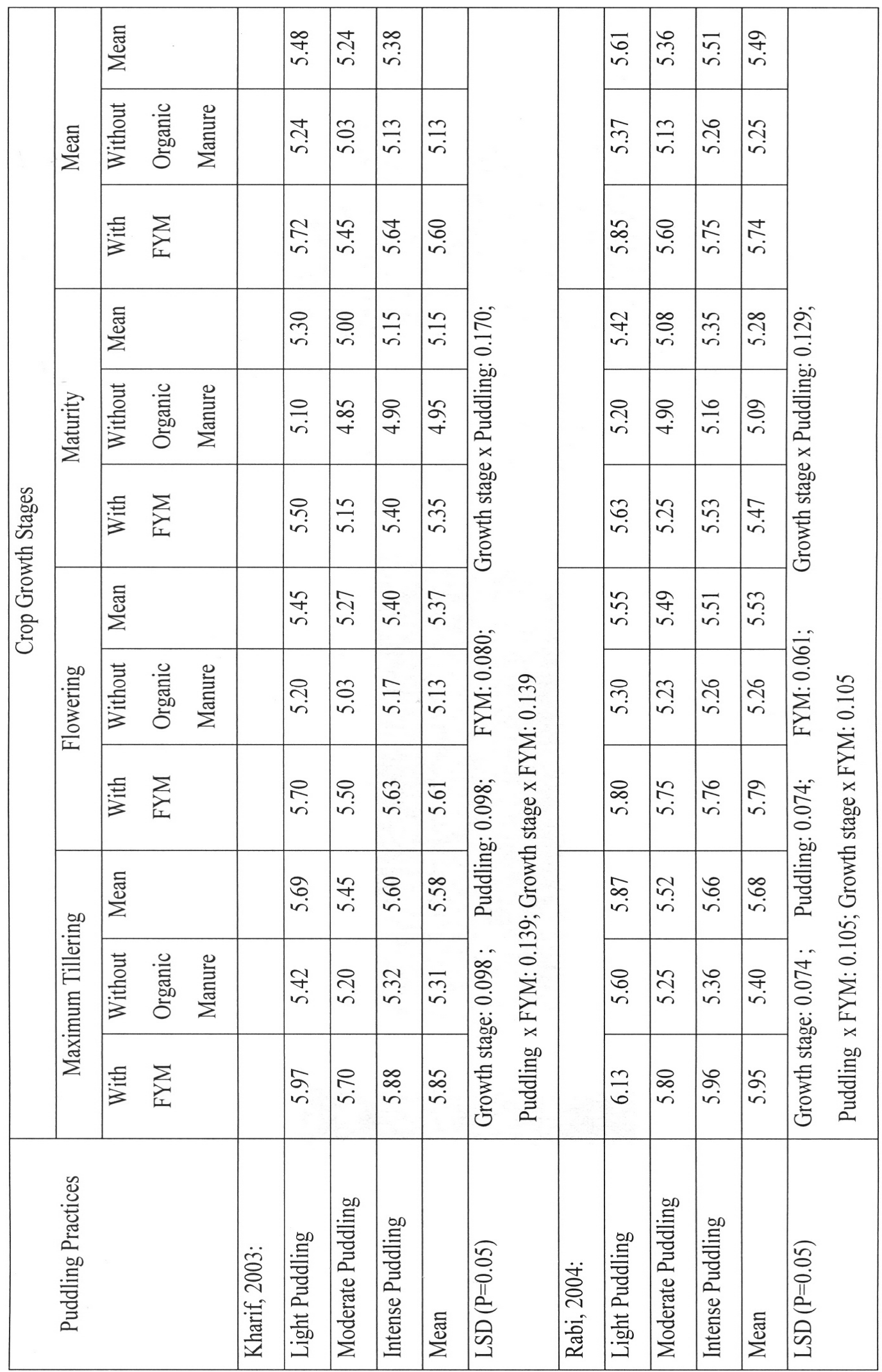


Addition of FYM resulted in a significant increase in the organic carbon level of rhizosphere soil from tillering to maturity stage of rice over that of FYM untreated plots, which was due to the additive effect of carbonaceous compounds of FYM (Mukherjee and Gaur, 1984). The organic carbon content of rhizosphere soil significantly decreased from tillering to maturity stage of rice due to greater utilization of organic carbonaceous materials by the increased number of micro-organisms resulting in higher breakdown of organic matter with a subsequent release of $\mathrm{CO}_{2}$ from the soil (Debnath et al., 1994). Organic carbon was positively and significantly correlated with microbial biomass carbon, total nitrogen content, ammonium nitrogen content and nitrate nitrogen content in the rice rhizosphere (Table 7).

\section{Total Nitrogen}

Compared to other puddling methods, conventional light puddling with country plough effectuated significant increase in the total $-\mathrm{N}$ content of rhizosphere during all the growth stages of rice (Table 3). The increase was further accelerated by the addition of FYM in soil. Light puddling resulted in less exposure of the soil particles leading to less proliferation of microorganisms. This in turn brought about lower mineralization of organic nitrogenous compounds protected in the lattice holes of minerals in the soil of rhizosphere.

Addition of FYM exerted significant increase in the total-N content of rhizosphere soil during each of the growth stages due to additive effect of nitrogenous components of the organic manure (Saenjan et al., 1992). Moreover, added FYM effectuated assymbiotic nitrogen fixation by free living aerobic and anaerobic $\mathrm{N}$-fixers in rice rhizophere. The level of total-N significantly decreased from tillering to maturity stage in the rhizosphere soil due to uptake of available $\mathrm{N}$ by the rice crop or loss of $\mathrm{N}$ through biotic and abiotic processes after mineralization of organic nitrogenous compounds in the rhizosphere of rice. More so, the capacity of free living $\mathrm{N}$-fixers to fix atmospheric nitrogen decreased with the advancement of the age of plants due to decreased rate of rhizo-deposition (Saha, 2000). Total-N content was significantly correlated with microbial biomass carbon, organic carbon, ammonium nitrogen content and nitrate nitrogen content in the rice rhizosphere (Table 7). 
Table 3. Effect of puddling practices and farm yard manure (FYM) on soil rhizosphere total nitrogen status $\left(\mathrm{g}^{\mathrm{kg}} \mathrm{g}^{-1}\right)$ at different crop growth stages during two rice growing seasons

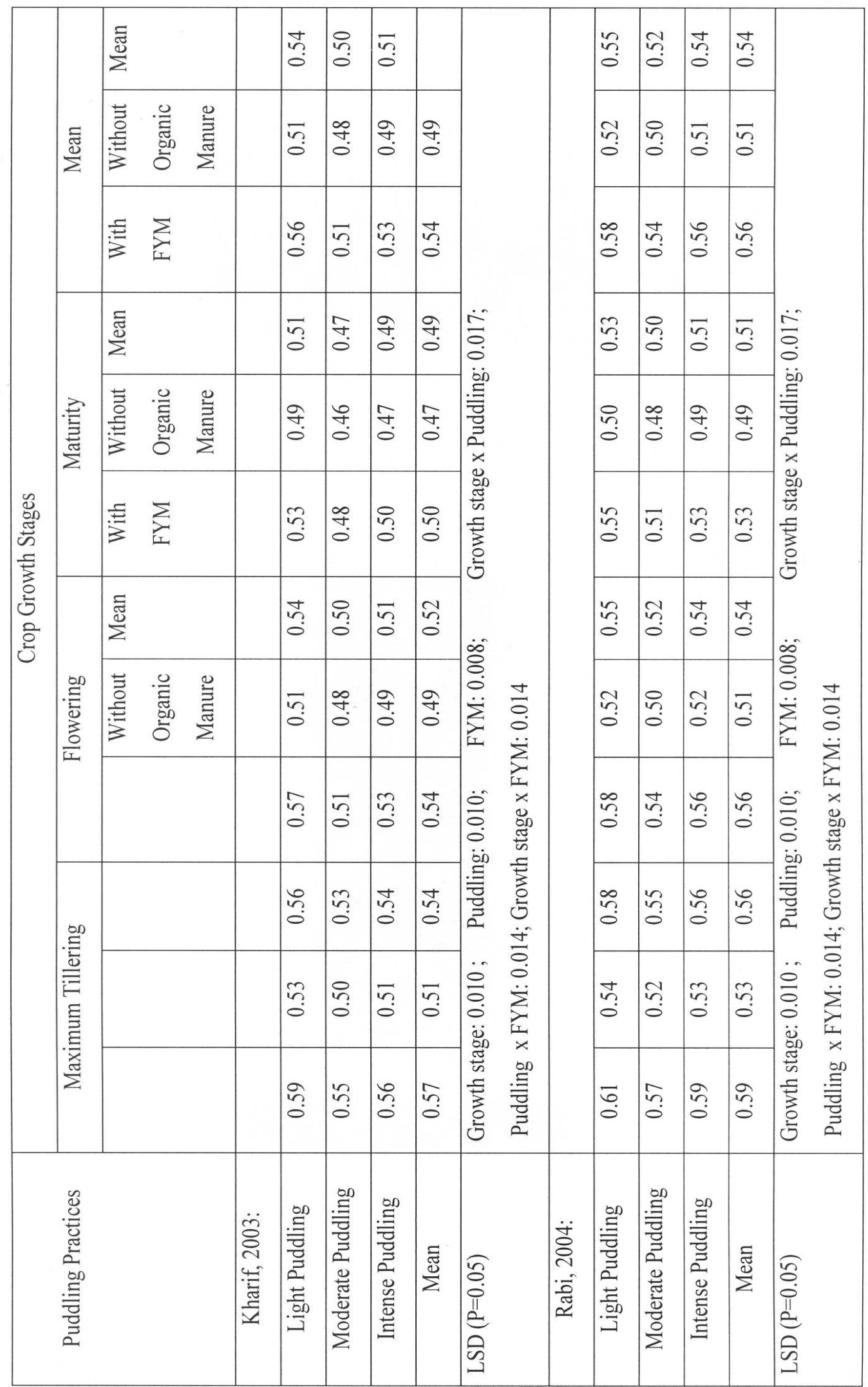




\section{Ammonium and Nitrate Nitrogen}

Among different puddling methods, while moderate puddling by tractor drawn cultivator resulted in the highest level of both ammonium and nitrate nitrogen in the rhizosphere soil at different growth stages of rice, the light puddling by country plough resulted in the lowest status (Table 4, 5).

Table 4. Effect of puddling practices and farm yard manure (FYM) on soil rhizosphere ammoniacal nitrogen status $\left(\mathrm{kg}_{\mathrm{g}} \mathrm{ha}^{-1}\right)$ at different crop growth stages during two rice growing seasons

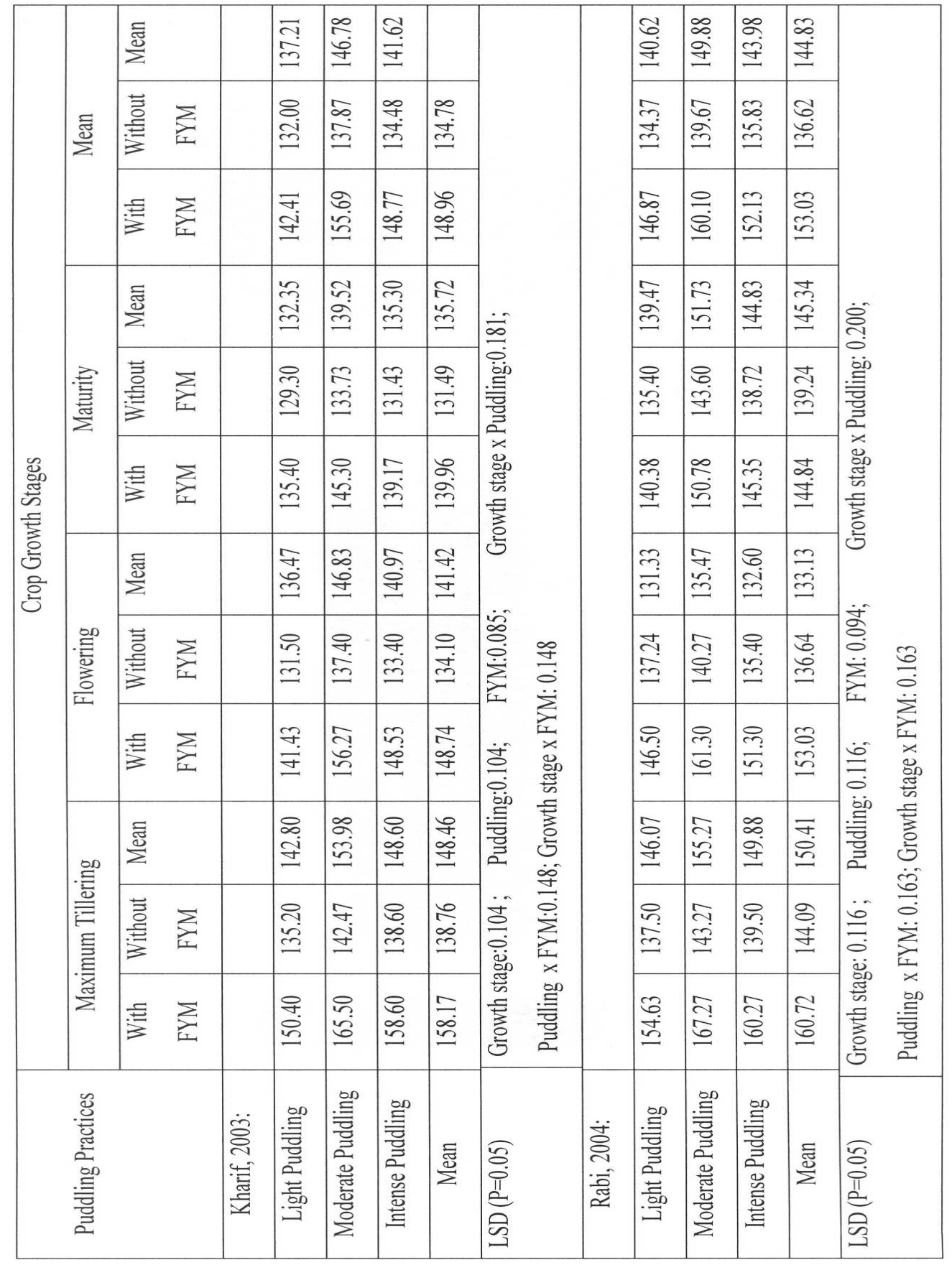


Addition of FYM, in general, improved the ammonium and nitrate nitrogen in the rhizosphere soil compared to the FYM untreated control soil. While the ammonium-N content of rhizosphere soil was highest during tillering stage, the nitrate- $\mathrm{N}$ content was the highest during flowering stage and that reflected the higher rate of nitrification during flowering stage of rice. Among different puddling methods, moderate puddling with tractor drawn cultivator resulted in the highest exposure of primary and secondary soil particles and furnished favorable conditions for microbial proliferation leading to greater mineralization of both native soil organic matter as well as added organic nitrogenous compounds.

Table 5. Effect of puddling practices and farm yard manure (FYM) on soil rhizosphere nitrate nitrogen status $\left(\mathrm{kg} . \mathrm{ha}^{-1}\right)$ at different crop growth stages during two rice growing seasons

\begin{tabular}{|c|c|c|c|c|c|c|c|c|c|c|c|c|c|c|c|c|c|}
\hline \multirow{12}{*}{ 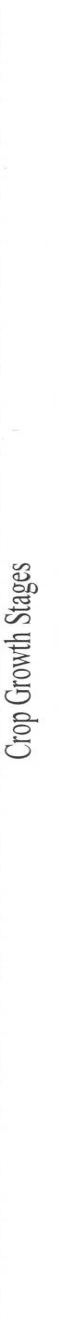 } & \multirow{3}{*}{${ }^{\overline{\mathbb{I}}}$} & \multicolumn{2}{|l|}{ 㞼 } & \multirow{2}{*}{\multicolumn{2}{|c|}{ 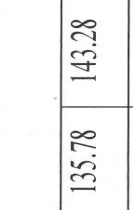 }} & $\begin{array}{l}\overline{\widehat{n}} \\
\text { 它 }\end{array}$ & 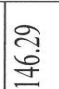 & & & & & $\begin{array}{l}3 \\
\text { 过 }\end{array}$ & $\begin{array}{l}\widetilde{\sigma} \\
\tilde{\Omega} \\
\tilde{\Omega}\end{array}$ & ్ㅗㅇ & 9 & & \\
\hline & & 言 & 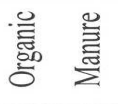 & & & 㺯 & $\begin{array}{l}\text { 音 } \\
\text { a }\end{array}$ & $\mid \begin{array}{l}\infty \\
\infty \\
\infty \\
= \\
=\end{array}$ & & & & 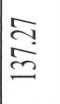 & 㟢 & 형 & 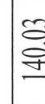 & & \\
\hline & & 言 & $\sum_{i}$ & & 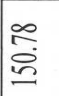 & 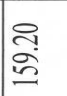 & $\begin{array}{l}\text { 㕝 } \\
\text { 惫 }\end{array}$ & 总 & & & & 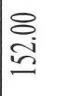 & 姲 & 空 & 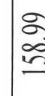 & & \\
\hline & & 离 & & & $\begin{array}{l}\bar{\infty} \\
\infty \\
\infty \\
\infty \\
=\end{array}$ & \begin{tabular}{|l}
$\tilde{\widetilde{F}}$ \\
学
\end{tabular} & $\stackrel{\overbrace{}}{\stackrel{\overbrace{}}{\Xi}}$ & 童 & $\frac{\dot{3}}{0}$ & & & 导 & בֶ: & 字 & 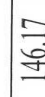 & & \\
\hline & 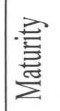 & 言 & 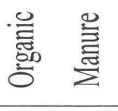 & & 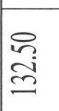 & 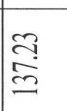 & 尽 & 志 & 咅 & & & 导 & 畩 & 跑 & हू & 跣 & \\
\hline & & 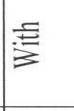 & $\sum_{\text {至 }}$ & & 量 & $\begin{array}{l}\text { 早 } \\
\text { 足 }\end{array}$ & $\begin{array}{l}8 \\
\frac{8}{9} \\
\frac{\sigma}{9}\end{array}$ & $\bar{\sigma}$ & 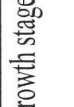 & & & 字 & 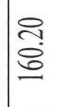 & 量 & 盟 & & \\
\hline & & 敢 & & & 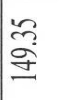 & 局 & శ్ & . & & & & 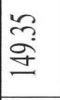 & 롱 & 㐫 & 疍 & & \\
\hline & 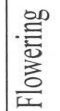 & 言 & 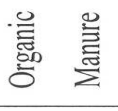 & & 疍 & 度 & $\begin{array}{l}\text { 导 } \\
\text { 守 }\end{array}$ & $\begin{array}{l}\approx \\
\tilde{\sigma} \\
\tilde{\theta}\end{array}$ & $\mid$ & $\frac{\tilde{m}}{6}$ & & $\underset{9}{\stackrel{P}{\dot{\Xi}}}$ & 軓 & 总 & 雪 & & $\dot{\vec{y}}$ \\
\hline & & 言 & $\sum_{i}$ & & $\begin{array}{l}\text { 早 } \\
\stackrel{0}{\circ} \\
:\end{array}$ & 季 & 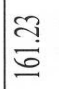 & 㗐 & & & & 总 & 总 & fo & 胥 & & 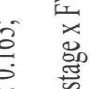 \\
\hline & 然 & $\sum_{\overline{\mathbb{E}}}^{\text {ह }}$ & & & 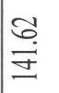 & 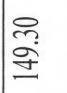 & $\begin{array}{l}\approx \\
\text { 过 } \\
\text { 年 }\end{array}$ & $\begin{array}{l}\text { 苦 } \\
\text { 守 }\end{array}$ & & 旁 & & 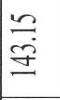 & 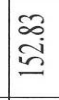 & 웅 & 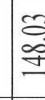 & & 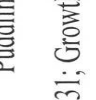 \\
\hline & 离 & 言 & 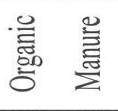 & & 昰 & 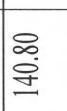 & శ్త్ర & 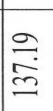 & $\begin{array}{l}\ddot{0} \\
\dot{g} \\
\dot{0} \\
\dot{g} \\
\dot{o}\end{array}$ & 离 & & 总 & 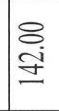 & $\begin{array}{l}\text { g } \\
\text { o. } \\
m \\
=\end{array}$ & $\begin{array}{ll}\infty \\
\infty \\
c\end{array}$ & & $\sum_{i=1}^{0}$ \\
\hline & $e^{\pi}$ & 吾 & $\sum_{i \leq 1}$ & & 吕 & 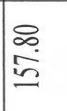 & $\begin{array}{l}\text { f } \\
\text { 吕 }\end{array}$ & 离 & 莺 & 哭 & & 畩 & 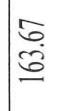 & 怘 & İ & & 宸 \\
\hline & 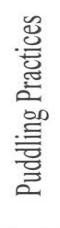 & & & 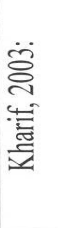 & 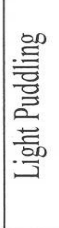 & 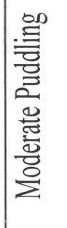 & 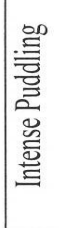 & $\frac{\bar{\Xi}}{\bar{z}}$ & 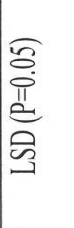 & & 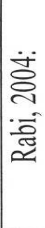 & 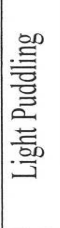 & 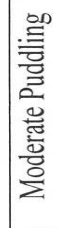 & 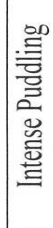 & 氖 & 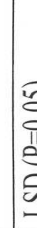 & $\frac{5}{5}$ \\
\hline
\end{tabular}


Higher amounts of ammonium and nitrate nitrogen in FYM treated soil were due to the additive effects of the mineralized organic nitrogen compounds of the organic manure (Mukherjee and Gaur, 1985). The highest level of ammonium-N at the tillering stage was due to greater rate of ammonification of organic manure (Mishra et al., 2001). Ammonium-N of the rhizosphere was significantly and positively correlated with microbial biomass carbon, organic carbon, total nitrogen content and nitrate nitrogen content in the rice rhizosphere (Table 7). The nitrate-N content of rice rhizosphere was significantly and positively correlated with microbial biomass carbon, organic carbon, ammonium nitrogen content and total nitrogen content (Table 7).

\section{Microbial Biomass Carbon}

Among different puddling methods, while conventional light puddling with country plough resulted in the highest level, moderate puddling with tractor drawn cultivator caused the lowest level of microbial biomass carbon in the rice rhizosphere throughout all the growth stages of rice (Table 6). The increment in the level of microbial biomass carbon was due to the impact of higher level of organic carbon (Table 2). The result substantiates the reports of Spieir et al. (1982). It is globally hypothesized that density of microbial population declines with the intensity of agricultural operation (Giller et al., 1997; Pankhurst et al., 1995). In the present investigation, a gradient of intensity of disturbance created by puddling existed. As in case of conventional light puddling with country plough, the disturbance was relatively low, and thus, microbial habitat was relatively protected. This resulted in higher microbial loading which in turn, effectuated higher level of microbial biomass carbon. Application of FYM effectuated a universal scaling up of microbial biomass carbon in rice rhizosphere. The results, thus, corroborated the findings of (Bhattacharjee et al., 2001). The level of microbial biomass carbon gradually reduced from tillering to maturity stage in the rice rhizosphere due to gradual loss of organic carbon during those periods as evidenced from Table 2. It has been estimated that as much as $40 \%$ of plant primary production may be lost through rhizodeposition (Lynch and Whipps, 1990) in the form of very essential vitamins, short chain fatty acids, carbohydrates, amino acids etc., for microbial growth. But with advancement of growth of rice, quality and quantity of rhizodeposition decreased due to senescence (Hütsch et al., 2002). Thus, abundance of microbial population, in general and microbial biomass, in particular, declined. 
Table 6. Effect of puddling practices and farm yard manure (FYM) on soil rhizosphere microbial biomass carbon status $\left(\mu g . g^{-1}\right)$ at different crop growth stages during two rice growing seasons

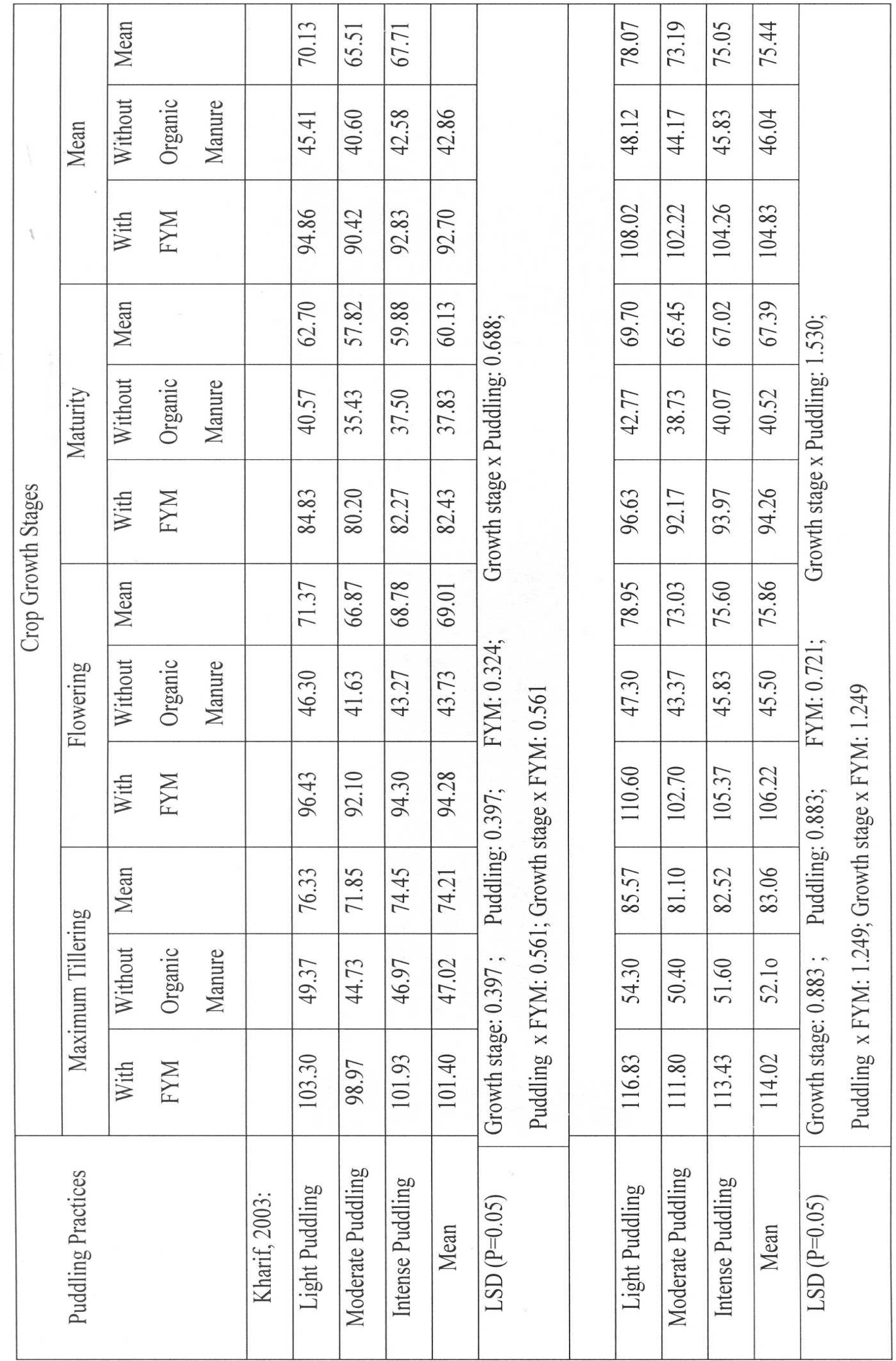


This is supported by the findings of Butler et al. (2004). With $14_{\mathrm{C}}$ labeled carbon the authors showed that the turnover of labeled rhizodeposition through dynamics of microbial biomass was different in different phenological stages of crop growth. Microbial biomass carbon level of the rice rhizosphere was significantly positively correlated with organic carbon, total nitrogen, ammonium nitrogen and nitrate nitrogen content (Table 7).

Table 7. Pearson Correlation Co-efficient among different parameters of rhizosphere soil of rice during two growing seasons

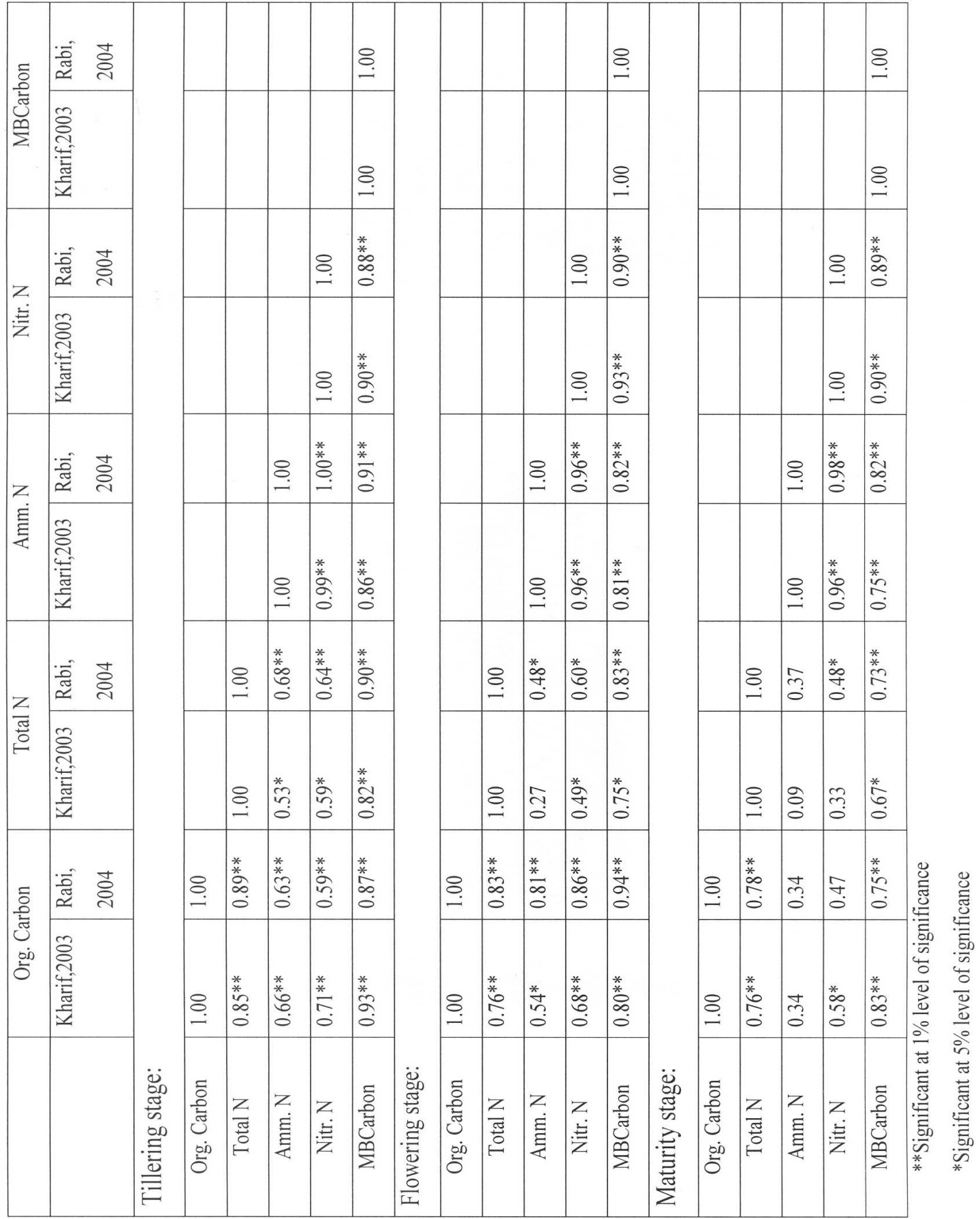


Conventional light puddling with country plough results in the lower microbial activity and so effectuates the highest build up of organic carbon, microbial biomass carbon but causes lower availability of plant available mineral nitrogen in the rhizosphere. Moderate puddling using tractor drawn cultivator, on the other hand, brings about higher mineralization of organic nitrogen and so causes an increment in the level of plant available mineral nitrogen in the rice rhizosphere. So, it is suggested that moderate puddling harnesses the best nitrogen availability in the rice rhizosphere in the critical growth stages, the impact of that is further accelerated through application of FYM.

Soil organic matter formation and development in rice fields is highly dependent on puddling intensity. Submergence makes added carbon recalcitrant and conserve for longer period while tillage withdraw the carbon balance. Thus, methods to maintain soil carbon level and aggressive tillage practices e.g. puddling are not compatible. Through further research knowledge to arrive at a delicate balance between applied organic residues and the intensity of puddling are needed for transplanting of rice seedlings and at the same time minimize agricultural impact on the environment.

\section{REFERENCES}

[1] Beare, M.H., Hendrix, P.F., Coleman, D.C. (1994): Water stable aggregates and organic matter fractions in conventional and no-tillage. - Soil Sci. Soc. Am. J. 58: 777-786.

[2] Bhattacharjee, P., Chakraborty, K., Chakraborty, A., Bhattacharjee, B. (2001): Microbial biomass and activities of soils amended with municipal solid waste compost. - J. Indian Soc. Soil Sci. 49(1): 98-104.

[3] Bouldin, D.R. (1986): The chemistry and biology of flooded soils in relation to the nitrogen economy of rice fields. - Fertilizer Research 9: 1-14.

[4] Bouyoucos, G.J. (1962): Hydrometer method improved for making particle size analysis in soils. - Agron. J. 54: 464-465.

[5] Broadbent, F.E. (1979): Mineralization of organic nitrogen in paddy soils. - In: Nitrogen and rice, I R R I, Manila, Philippines, Pp. 105-118.

[6] Butler, J.L., Bottomley, P.J., Griffith, S.M., Myrold, D.D. (2004): Distribution and turnover of recently fixed photosynthate in ryegrass rhizospheres. - Soil. Biol. Biochem 36:371-382.

[7] Campbell, C.A., McConkey, B.G., Bierderbeck, V.O., Zenner, R.P., Curpin, D., Peru, M.R. (1998): Long term effects of tillage and fallow frequency on soil quality attributes in a clay soil in semi-arid southwestern Saskatchewan. - Soil Till. Res. 46: 135-144.

[8] Campbell, C.A., McConkey, B.G., Zentner, R.P., Selles, F., Curtin, D. (1996): Tillage and crop rotation effects on soil organic carbon and nitrogen in a coarse textured Typic haploborrol in South Western Saskatchewan. - Soil Till. Res. 37: 3-14.

[9] Cassman, K.G., De Datta, S.K., Olk, D.C., Alcantara, J., Samson, M., Descalsota, J., Dizon, A. (1995): Yield decline and the nitrogen economy of long term experiments on continuous irrigated rice systems in the tropics. - In: Lal, R., Stewart, B.A. (eds) Soil Management: Experimental basis for sustainability and environmental quality. Adv. Soil Sci., CRC Press, Boca Raton, FL, pp. 181-222.

[10] Costantini, A., Cosentino, D., Segat, A. (1996): Influence of tillage systems on biological properties of a Typic Argiudoll soil under continuous maize in central Argentina. - Soil Till. Res. 38: 265-271.

[11] De Datta, S.K., Broadbent, F.E. (1990): Nitrogen use efficiency of 24 rice genotypes on an nitrogen deficient soil. - Field Crops Res. 23: 81-92. 
[12] Debnath, A., Das, A.C., Mukherjee, D. (1994): Studies on the decomposition of organic wastes in soil. - Microbiol. Res. 149: 195-201.

[13] Diaz-Zorita, M., Grove, J.H. (2002): Duration of tillage management affects carbon and phosphorus stratification in phosphatic Paleudalfs. - Soil Till. Res. 66: 165-174.

[14] Dick, R.P., Rasmussen, P.E., Kerle, E.A. (1989): Influence of long-term residue management on soil enzyme activities in relation to soil chemical properties of a wheat fallow system. - Biol. Fertil. Soil 6:159-164.

[15] Doran, J.W. (1980): Microbial change with residue management and residue tillage. Soil Sci. Soc. Am. J. 44: 518-524.

[16] Doran, J.W., Parkin, T.B. (1994): Defining and assessing soil quality. - In: Defining soil quality for a sustainable environment, Soil Sci. Soc. Am., Madison WI, USA, pp. 3-21.

[17] Duxbury, J.M., Abrol, I.P., Gupta, R.K., Bronson, K.F.(2000): Analysis of long term soil fertility experiments with rice-wheat rotations in South Asia. - In: Abrol, I.P. (ed.) Long term soil fertility experiments with rice-wheat rotations in South Asia, Rice-Wheat Consortium Paper Series No.6. Rice-Wheat Consortium for the Indo-Gangetic Plains. New Delhi, India, pp. 7-22.

[18] Flinn, J.C., De Datta, S.K.(1984): Trends in irrigated rice yields under intensive cropping at Philippine research stations. - Field Crops Research. 9: 1-15.

[19] Follett, R.F., Schimel, D.S. (1989): Effect of tillage practices on microbial biomass dynamics. - Soil Sci. Soc. Am. J. 53: 1091-1096.

[20] Giller, K.E., Beare, M.H., Lavelle, R., Izac, A.M.N., Swift, J.J. (1997): Agricultural intensification, soil biodiversity and agroecosystem fallow. - Appl. Soil. Ecol. 6: 3-16.

[21] Gregorich, E.G., Carter, M.R., Angers, D.A., Monreal, C.M., Ellert, B.H. (1994): Towards a minimum dataset to assess soil organic matter quality in agricultural soils. Can. J. Soil Sci. 74: 367-385.

[22] Hütsch, B.W., Augustin, J., Merbach, W. (2002): Plant rhizodeposition - an important source for carbon turnover in soils. - Journal of Plant Nutrition and Soil Sci. 165: 397407.

[23] Jackson, M.L. (1973): Soil chemical analysis. - Prentic Hall of India Pvt. Ltd., New Delhi, pp. 498.

[24] Joergensen, R.G. (1995): Microbial biomass. - In: Alef, K., Nannipieri, P. (eds.) Methods in Applied Microbiology and Bio-chemistry, Academic Press, pp. 382-386.

[25] Kamble, H.G., Srivastava, A.P. (2003): Training manual on Mechanisation of Experimental Plots. - ICAR, New Delhi, India, 134 pp.

[26] Kundu, D.K., Ladha, J.K. (1995): Efficient management of soil and biologically fixed nitrogen in intensively cultivated rice soils. - Soil Biol. Biochem. 27: 431-439.

[27] Lal, R., Bruce, J.P.(1999): The potential of world crop land soils to sequester carbon and mitigate the green house effect. - Environ. Sci. Policy. 2: 177-185.

[28] Lal, R., Kimble, J.M., Follett, R.F., Stewart, B.A. (1997): Soil processes and carbon cycles. - C R C Press, Boca Raton, FL.

[29] Lynch, J.M., Whipps, J.M. (1990): Substrate flow in the rhizosphere. - Plant and Soil 129: 1-10.

[30] Mishra, B.; Sharma, P.K., Bronson, K.F. (2001): Decomposition of rice straw and mineralization of carbon, nitrogen, phosphorus and potassium in wheat field soil in Western Uttarpradesh. - J. Indian Soc. Soil Sci. 49(3): 419-424.

[31] Morris, D.R., Gilbert, R.A., Reicosky, D.C., Gesch, R.W.(2004): Oxidation potential of soil organic matter in Histosols under different tillage methods. - Soil Sci. Soc. Am. J. 68: 817-826.

[32] Mukherjee, D., Gaur, A.C. (1984): Effect of incorporation of organic materials on some chemical properties and yield of paddy. - Indian Agric. 28: 215-219.

[33] Mukherjee, D., Gaur, A.C. (1985): Recycling of organic matter entailing some physicochemical and microbiological properties of soil in relation to yield of wheat. - Indian Agric. 29: 93-99. 
[34] Olsen, S.R., Cole, C.V., Watanabe, F.S., Dean, L.A. (1954): Estimation of available phosphorus in soil by extraction with sodium bicarbonate. - U.S. Department of Agriculture circular 939.

[35] Pankhurst, C.E., Ophel-Keller, K., Double, B.M., Gupta, V.V.S.R. (1995): Biodiversity of soil microbial communities in agricultural system. - Biodiv. cons. 5: 197-209.

[36] Paustian, K., Collins, H.P., Paul, E.A. (1997): Management controls on soil carbon. - In: Paustian, K., Elliott, E.T., Cole, C.V., (eds.) Soil Organic matter in temperate agroecosystems, C R C Press, Boca Raton, FL, pp. 15-49.

[37] Reicosky, D.C., Lindstrom, M.J. (1995): Impact of fall tillage and short-term carbon dioxide flux. P. 177-187, - In: Lal, R. et al. (eds.) Soils and Global Change, Lewis Publ., Boca Raton, FL.

[38] Saenjan, P., Dejbhimon, K., Paiboonsak, S. (1992): Physical and chemical properties of sandy soils receiving long term organic matter as influenced by different agricultural practices. - Khon-Kaen Agricultural Journal 20(3): 124-139.

[39] Saha, N. (2000): Influence of organic manures with the inoculation of nitrogen fixing and phosphate solubilizing bacteria on the microbial population and nitrogen fixing and phosphate solubilizing power of ginger rhizophere. - Ph.D thesis, BCKV, Mohanpur, India.

[40] Spieir, T.W., Ross, D.J., Orchard, V.A., Cairns, A., Paniser, E.A. (1982): Bio-chemical and microbiological properties of West coast wet land soil at different stages of pasture development. - New Zealand J. Sci. 25: 352-359.

[41] Swaminathan, M.S. (1993): Challenges and opportunities in rice research. - In: Proc. Int. Symp. New frontiers in Rice Research, November 15-18, 1990, Directorate of Rice Research, Hyderabad, India, pp. 1-2.

[42] Taimani, B.K., Verma, K.P.S. (1998): Rice based farming systems: Development strategies and policy - In: Rainfed rice for sustainable food security, Proc. of the Int. Symp. Rainfed rice for Sustainable food security, September 23-25, Cuttack, Orissa, India, pp. 21-23.

[43] Wada, G., Shoji, S., Mae, T. (1986): Relationship between nitrogen absorption and growth and yield of rice plants. - Japan Agricultural Research Quarterly 20: 135-145.

[44] Walkley, A.J., Black, J.A. (1934): Estimation of soil organic carbon by the chromic acid titration method. - Soil Sci. 37: 29-38.

[45] Yadav, R.L., Dwivedi, B.S., Pandey, P.S. (2000): Rice-wheat cropping system: assessment of suatainability under green manuring and chemical fertilizer inputs. - Field Crops Res. 65: 15-30.

[46] Yadav, R.L., Yadav, D.S., Singh, R.M., Kumar, A. (1998): Long-term effects of inorganic fertilizer inputs on crop productivityin rice - wheat cropping system. - Nutr. Cycling Agroecosyst. 51: 193-200.

[47] Zibilske, L.M., Bradford, J.M., Smart, J.R. (2002): Conservation tillage induced changes in organic carbon, total nitrogen and available phosphorus in a semi-arid alkaline subtropical soil. - Soil Till. Res. 66: 153-163. 